\title{
83. 名古屋港水族館北館の照明設備
}

\author{
丸山 豊弘 田丸 雅和 石田 浩二 伊藤 喜隆 \\ （松下電工株式会社）（株式会社大建設計）
}

\section{1.はじめに}

名古屋港水族館北館（図 1 ）は約 3000 人収容のスタンドを備えた 世界最大級のメインプールを中心に、7槽の展示水槽、 4 槽の治療・ 予備水槽からなる施設である。

これらの水槽では、イルカ等の大型海洋哺乳動物の躍動感あるパフ オーマンスを楽しみながら、動物が本来持つ生態に、水中および水面 上の両面より間近に迫ることができるよう、様々な照明設備が設置さ れている。

\section{2. 照明設備の概要}

〈大洋 (メインプール) >

2000Wショートアークメタルハライドランプ投光器 (瞬時再始動装置 内蔵）をスタンド上部のトラスに 21 台設置。平均演色評価数 (Ra) 90 の高演色形ランプの採用と、周囲への光漏れが少なくシャープな配光 特性を持つ器具の組合せにより、水深 $12 \mathrm{~m}$ の水底までも明るく照ら し出している。さらに手前のステージ上には演出用に500W八ロゲン 電球の舞台照明用器具 9 台設置している。(図 2 )

<オーロラの海 $>$

$500 W$ ハロゲン電球の舞台用照明器具および投光器計 222 台にて、 カナダのハドソン湾をイメージした空間を時間と共に壁面の色や明 るさが変わるように演出している。(図 3 )

$<$ 日本の海 $>$

水中からも明るく見えるよう、水面上約 $3 \mathrm{~m}$ の高さに $400 \mathrm{~W}$ メル ハライドランプ投光器を 6 台設置。

また投光器およびポールは耐食性を考慮して全てフッ素樹脂塗装 としている。

〈エントランス $>$

$150 \mathrm{~W}$ コンパクト形メタルハライドランプと $\phi 150 \mathrm{~mm}$ の導光式光パ イプ約 $8 \mathrm{~m}$ を 5 連結及び 3 連結にて配置している。灯具部分も光が漏 れる構造とすることにより、 $40 \mathrm{~m}+24 \mathrm{~m}$ もの連続光を実現。(図 4 ) <からくり広場 $>$

70Wコンパクト形メタルハライドランプを採用した $\phi 170 \mathrm{~mm}$ 全高 $2.9 \mathrm{~m}$ のライトポールと狭角配光投光器の組合せにより、空間と地上 面に真っ直ぐ伸びる光を演出。他の低ポール照明と足元灯ともに名古 屋港におけるランドマークとなっている。(図 5)

\section{3.おわりに}

本照明設備は名古屋港の新たなシンボルとなった水族館の演出に おおいに貢献している。

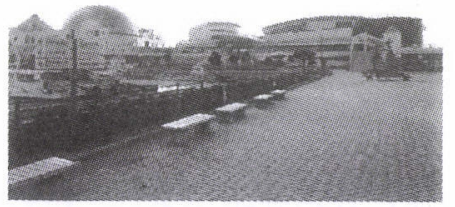

図 1 名古屋港水族館

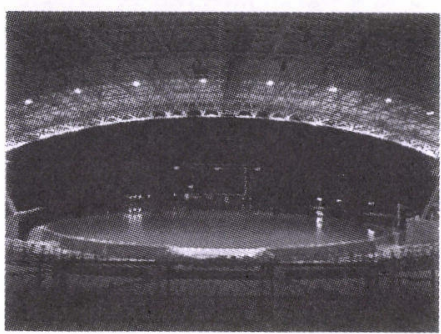

図 2 大洋(メイプール)

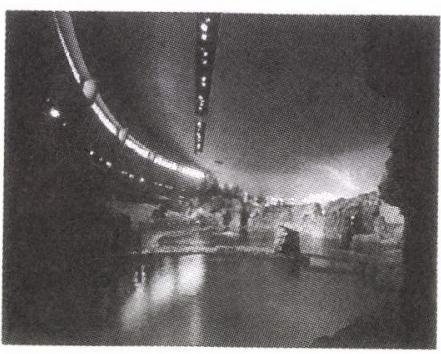

図 3 オーロラの海

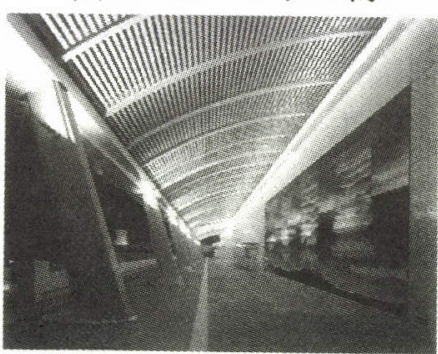

図 4 エントランス

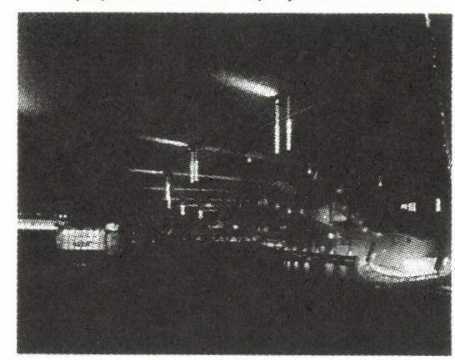

図 5 からくり広場

Lighting facilities for North side in the Port of Nagoya Public Aquarium. Toyohiro Maruyama, Masakazu Tamaru, Koji Ishida and Yoshitaka Ito 